\title{
Costureiras, mucamas, lavadeiras e vendedoras: o trabalho feminino no século XIX e o cuidado com as roupas (Rio de Janeiro, 1850-1920)
}

\author{
Joana de Moraes Monteleone
}

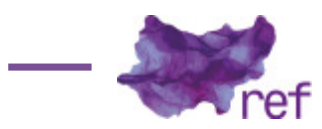

\begin{abstract}
Resumo: O trabalho assalariado feminino se transforma no século XIX, enquanto se desenvolve o capitalismo. Se, por um lado, as mulheres passam a ser vistas como consumidoras de mercadorias, por outro, esse consumo dá início a uma série de transformações nas suas vidas. As mulheres passam a sair da casa para comprar, em especial, roupas. A indústria de confecção, que começa a partir de pequenos ateliês, abre espaço para novos tipos de trabalho feminino remunerados: vendedoras, costureiras, fazedoras de chapéus. Multiplicam-se os trabalhos femininos no cuidado com a roupa e no vestir-se das mulheres de elite. Mas são as mucamas, as costureiras e as lavadeiras, geralmente escravas, que vão transformar o tipo de trabalho feito por mulheres no século XIX.
\end{abstract}

Palavras-chave: história, trabalho feminino, urbanização, escravidão, indústria, Brasil

Dressmakers, Maids, Washerwomen and Saleswomen: Women's Work in The Nineteenth Century and the Care for Clothes (Rio de Janeiro, 1850-1920)

Abstract: Female wage labor transforms itself during the nineteenth century as capitalism develops. If, on the one hand, women are seen as consumers of goods, on the other, this consumption initiates a series of transformations in their lives. Women come out of the house specially to buy clothes. The garment industry, which starts from small ateliers, opens up space for new types of paid female work: saleswomen, dressmakers, hat makers. Women's work is multiplied in the care of the clothes and in the dressing of the elite women. But it is the maids, seamstresses and washerwomen, usually slaves, who will transform the kind of work done by women in the nineteenth century.

Keywords: History, Female Labor, Urbanization, Slavery, Industry, Brazil

Ao longo de todo o século XIX, costurar em casa era muito comum. Esperava-se que as mulheres soubessem cuidar da roupa da casa, que incluía um sem número de remendos, recosturas e transformações - além de inúmeras lavagens e do tempo dispendido passando as roupas todas. Todo esse trabalho significava um treinamento desde a infância, para as meninas. Nas famílias mais abastadas, não era incomum contratar-se, entre os diversos criados da casa, uma costureira para cuidar das roupas da família. Era um fenômeno que fazia parte da cultura ocidental e, no Brasil, costurar, lavar e cuidar das roupas era dos mais importantes afazeres domésticos, ao lado da cozinha. Geralmente, esses afazeres eram feitos por escravas domésticas.

Mesmo em famílias remediadas, os cuidados com a roupa tomavam grande parte do tempo dos afazeres domésticos. Os cuidados com as roupas e com os panos da casa estavam sempre nas preocupações das donas-de-casa, de suas criadas-escravas, mucamas, costureiras e lavadeiras. Apresentar-se socialmente com roupas adequadas fazia parte de um sistema de distinção social profundamente entranhado na sociedade do século XIX. Gilda de Mello e Souza analisa esse fenômeno em $O$ espírito das roupas: 
Isto porque a vestimenta é uma linguagem simbólica, um estratagema de que o homem sempre se serviu para tornar inteligíveis uma série de ideias como o estado emocional, as ocasiões sociais, a ocupação ou nível de portador. Cada classe, por exemplo, possuía um certo número de sinais que a caracterizam: uma amplidão determinada da saia das mulheres ou do gibão dos homens, um dado comprimento ou uma dada largura dos sapatos, uma extensão diversa da cauda, dos véus ou das mangas. Tais recursos, que à medida que se elevava na escala social se tornavam mais exagerados, teriam como objetivo \&\#091;..\&\#093; demonstrar através, do desconforto, a todos os observadores, que seu portador não estava empenhado em nenhuma espécie de trabalho produtivo e pertencia, por conseguinte, à classe privilegiada, à classe ociosa. (SOUZA, 1987, p. 125)

Esse sistema de distinção social, mais visível, e que necessitava de maior investimento para o guarda-roupa feminino, precisava de uma grande quantidade de tempo e de criadas-escravas para o cuidado das roupas. Marina Maluf lembra que "No espaço urbano, a identificação da condição social das camadas superiores podia ser feita na figura da mulher, que ostentava riqueza através das roupas, adereços, atitudes e gestos codificados pela moda" (MALUF, 1994, p. 188). Muitas vezes, nas visitas aos centros da cidade, as mulheres de elite iam na frente, seguidas por suas escravas, que também ostentavam símbolos de riqueza da família. Conforme a luta pela abolição da escravidão ganhava força - e passava a ser mal vista em determinados círculos sociais - a escrava negra dava origem a outro tipo de distinção social, a criada branca imigrante.

Foi nas cidades, com as mudanças de comportamentos e atitudes em relação às saídas das mulheres de elite às ruas, em meados do século XIX, que essa quantidade de criados e trabalhadores domésticos que se dedicavam aos cuidados com as roupas se multiplicaram. Com a abolição do tráfico, em 1850, a crescente e intensa imigração estrangeira e o êxodo rural, os centros urbanos reuniram uma quantidade de mão-de-obra, basicamente feminina, disponível para esse trabalho. Desta forma, ao lado da criadagem escrava, que cuidava das roupas dentro das casas, surgiu um novo tipo de trabalho feminino especializado, ligado à confecção de roupas em ateliês de moda e lojas, as vendedoras, as modistas, as jornalistas de moda (Vania Carneiro CARVALHO, 2008, p. 248).

Na época, os criados domésticos em casas e sobrados urbanos se multiplicaram. Se para os homens pobres livres viver de pequenos serviços temporários era uma maneira de sobreviver, para as mulheres livres pobres tornar-se uma criada era uma maneira de conseguir alguma maneira estável de viver, com abrigo, roupas, comidas e, eventualmente, remédios, fornecidos pela patroa. No Rio de Janeiro, em 1870 , " $71 \%$ das mulheres ativas eram criadas, o que significava 34 mil mulheres trabalhando como mucamas, pajens, amas-de-leite, cozinheiras, copeiras, arrumadeiras, carregadoras de água, lavadeiras, passadeiras e costureiras. Brancas e negras, livres ou escravas, elas trabalhavam juntas, exercendo atividades semelhantes." Muitas eram escravas, outras, mesmo livres, trabalhavam por casa e comida (CARVALHO, 2008, p. 248). Em 1872, 2/3 das mulheres livres estavam empregadas no serviço doméstico na corte imperial.

Além de se empregarem como criadas, Maria Odila Leite da Silva Dias mostra, com suas pesquisas, que algumas mulheres também podiam viver de pequenos expedientes ligados à lida doméstica, como vender quitandas ou fazer costuras para "fora". Muitas, a imensa maioria, eram escravas, trabalhavam para outras mulheres, vendendo quitandas na rua ou levando e trazendo roupas limpas e costuras. (DIAS, 1984, p. 133-140). Richard Graham vai falar em uma rede quitandeiras escravas em Salvador. (GRAHAM, 2013.)

Sandra Lauderdale Graham vai mostrar que a maioria das mulheres trabalhava, cerca de $70 \%$, fossem elas livres ou escravas. Em 1870, o censo imperial estimou em $63 \%$ a quantidade de mulheres livres engajadas em alguma ocupação remunerada. "Em 1906, quase a metade de todas as mulheres em idade de trabalho se declarara empregada" (GRAHAM, 1988, p. 17).

As condições desse abundante trabalho feminino eram as piores possíveis: sub-remuneradas (quando eram remuneradas), em posições subalternas e degradantes, vistas pelos patrões como disponíveis sexualmente, invisíveis dentro dos sobrados.

Em sua obra Proteção e obediência, a historiadora Sandra Graham, faz um estudo sobre patrões e criadas, onde diz quanto ganhava uma costureira, além de evidenciar um hábito comum nas famílias cariocas: a presença de costureiras residentes e livres (GRAHAM, 1988). Uma costureira que morasse na casa esperava receber em torno de 18 dólares para coser à mão e à máquina, enquanto uma lavadeira portuguesa pedia cerca de 14 dólares pelos mesmos serviços. Uma doméstica, assim como uma mulher que 'lave, carregue água, venda doces na rua', ganhava entre oito e nove dólares. Para amamentar bebês, as donas de casa pagavam às amas de leite os salários mais altos de todos: 20 dólares por mês, além de casa e comida (GRAHAM, 1988, p. 27). ${ }^{1}$

\footnotetext{
1 Na época em que publicou seu livro, em 1988, Sandra Graham fez uma atualização monetária da seguinte maneira: "Durante o século XIX e parte do século XX, a moeda brasileira era o mil-réis, grafado $1 \$ 000$. O conto, correspondente a mil mil-réis, era grafado 1:000\$000. Entre 1860 e 1910, a cotação do mil-réis, relativa à moeda americana, variou de 0,55 dólar no ponto mais alto (1863-1875) a 0,15 dólar no ponto mais baixo (1898-1899); em 1910, o mil-réis valia 0,33 dólar. " (GRAHAM, 1988, p. 9).
} 
A historiadora recupera os preços de criadas de costura para mostrar como as costureiras faziam parte da criadagem doméstica de uma casa abastada. O cuidar das roupas implicava num sem-número de atividades diárias bastante extenuantes: lavar, secar, passar, engomar, costurar, remendar, que eram tão importantes para o cotidiano de uma casa quanto a constante feitura de alimentos para as mais diversas refeições.

As ocupações de cozinheira e costureira misturavam-se muitas vezes. Machado de Assis, em Memórias póstumas de Brás Cubas, escreveu sobre uma viúva pobre livre, que não apenas fazia doces para sobreviver, mas entregava costuras: "Fazia doces, que era o seu ofício, mas cozia também, de dia e de noite, com afinco, para três ou quatro lojas \&\#091;...\&\#093;. A filha \&\#091;...\&\#093; levando-a consigo, quando tinha de entregar costuras" (Joaquim Maria Machado de ASSIS, 1999, p. 99).

Muitas mulheres da corte possuíam mucamas, escravas que cuidavam de suas joias, cabelos e coisas, que as acompanhavam em compras na cidade ou nos banhos de mar recomendados pelos médicos, e que também cuidavam de suas roupas. Eram as mucamas que fechavam os broches de ouro, amarravam as correntes, davam corda nos relógios de bolso, apertavam os laços dos espartilhos, lavavam e passavam rendas e roupas de baixo, faziam bainhas. Lucíola, personagem de José de Alencar no romance com o mesmo nome da protagonista, mostra, numa cena, o papel das mucamas no cotidiano das mulheres abastadas. Ao sair para um passeio, "\&\#091; ...\&\#093; a mucama lhe apresentava as luvas \&\#091; ..\&\#093;" (ALENCAR, 2012, p. 113).

Debret nota como as mucamas-escravas eram também as grandes responsáveis pelo guarda-roupa elegante das senhoras e meninas ricas: "Uma família rica tem sempre negras lavadeiras e uma mucama encarregada especialmente de passar as peças finas, o que a ocupa pelo menos dois dias por semana, pois uma senhora só usa roupa passada de fresco e renova mesmo sua vestimenta para sair uma segunda vez de manhã (Jean Baptiste DEBRET, 1940, p. 274). Também Aluísio Azevedo escreveu, em Casa de pensão: "Tinha \&\#091; ...\&\#093; a mucama para lavar-Ihe e engomar-Ihe a roupa \&\#091; ...\&\#093;" (AZEVEDO, 1960, p. 246).

As mucamas, escravas de dentro de casa, dedicadas à senhora e às crianças, deveriam quase que, necessariamente, saber costurar, ao menos o básico, como fazer barras de vestidos, pregar botões, realizar pequenos remendos. Machado de Assis notava que: "- Há de ser alguma pałuscada, dizia ela, mudando a posição de um alfinete. -- Benedita, vê se a barra está boa. -Está, sinhá, respondia a mucama de cócoras no chão \&\#091; ...\&\#093;" (ASSIS, 1999, p. 271). Em Girândola de Amores, de Aluísio Azevedo, Januária, velha mucama, ajeitava o vestido de noiva de Clorinda, de quem havia sido mucama desde criança.

Clorinda acabava de pôr seu véu de noiva e, de costas para o espelho, olhava por sobre o ombro a cauda do vestido. A velha Januária pregava-lhe \&\#091;...\&\#093; o último alfinete dourado \&\#091;...\&\#093;. Aos pés de Clorinda \&\#091;...\&\#093; uma mucama arranjava-lhe cuidadosamente a barra do vestido, compunha e ordenava os folhos e desfazia e ajeitava as pregas do cetim \&\#091; ...\&\#093; Estava linda, assim, toda de branco, com o seu longo véu de filó, que lhe envolvia o busto gracioso, deixando todavia perceber o doce relevo da cabeça, engrinaldada de pálidas flores de laranjeira \&\#091;...\&\#093; (AZEVEDO, 1960).

Assim como as criadas de quarto e mucamas, as costureiras de família também podiam fazer parte da criadagem, que trabalhava próxima à dona da casa. Senhoras abastadas não compravam, sempre, roupas na Europa - as viagens se tornariam mais frequentes apenas no final do século XIX e importação de roupas prontas oscilava entre 1 e $3 \%$ das importações entre 1850 e 1909 (GRAHAM, 1973, Apêndice 3).

Eram as modistas e as lojas de tecidos, como a Wallterstein, na corte, que copiavam modelos europeus que chegavam ao Brasil por meio de revistas ilustradas e gravuras. O Correio das modas editado por dois períodos distintos no Rio de Janeiro, muitas vezes supriu essa necessidade de informação sobre as mudanças na moda, e o mesmo fizeram diversos outros veículos de informação para as mulheres.

As revistas, gravuras, ilustrações ou publicações de moda geralmente publicavam um texto descrito ao lado da imagem de uma gravura de moda. Muitos ainda traziam moldes-padrão impressos em papel-seda em que uma modista ou costureira podia trabalhar como base, ou adaptar para o tamanho de sua cliente ou senhora. Mas esses eram serviços superespecializados, que nem toda casa podia pagar. Geralmente, as costureiras e modistas eram alugadas por dia para serviços mais simples como remendar e recosturar a roupa da família.

Esse hábito, de uma costureira por dia, por semana ou por mês não era apenas brasileiro. Na Europa, assim como aqui, esse tipo de serviço doméstico sobreviveu por muitas décadas, até meados do século XX. Natália Ginzburg, escritora italiana e mãe do historiador Carlo Ginzburg, conta em seu livro de memórias, Léxico familiar, sobre as diversas costureiras de sua mãe, que iam e vinham conforme passavam os anos e que acompanhavam a vida em família. "Essa Rina era uma espécie de costureira a domicilio, porém boa somente para revirar nossos casacos e remendar as calças. Não fazia roupas" (GINZBURG, 2009, p. 41). 
O trabalho de modistas e costureiras que faziam roupas em casa diminuiu quando as máquinas de costura se tornaram mais comuns no Rio de Janeiro, em meados da década de 1870. Mas as costureiras de remendos continuaram a existir por muito tempo. Elas trabalhavam alguns dias por semana, revezando-se em diferentes casas. Se aprendessem também a costurar à máquina, sabiam que teriam trabalho garantido, seja em casa de famílias muito abastadas (e que poderiam comprar uma máquina de costura própria), seja em ateliês (GRAHAM, 1988, p. 51).

Boas mucamas e lavadeiras, que sabiam costurar, lavar e passar, valiam bastante nos mercados que vendiam escravos, nas cidades brasileiras no século XIX. Diversos anúncios de jornal destacavam as qualidades de escravas costureiras, que podiam ser alugadas por dia. Gilberto Freyre destaca um anúncio de Recife: "Precisa-se comprar uma mulata moça que seja perfeita costureira de agulha e tesoura, paga-se bem agradando as suas qualidades: na rua do Trapiche, Recife, n. 40, se dirá quem a pretende" (FREYRE, 1979, p. 9).

As moças também podiam ser vendidas para modistas, que as empregariam em seus ateliês: "Vende-se uma escrava muito moça, bonita figura que sabe cozinhar e engomar. É uma perfeita costureira própria para qualquer modista: na botica de Joaquim Ignacio Ribeiro Junior na praça da Boa Vista" (FREYRE, 1979. p. 9).

Esse tipo de trabalho escravo especializado modificou as relações de trabalho de maneira profunda e duradoura (FREYRE, 1979, p. 9).

O pagamento por essas tarefas domésticas, com o passar do século XIX e o fim do tráfico (e mesmo após a abolição da escravatura), profissionalizou-se. Ou seja, esses serviços passaram a ser passíveis de recebimento de salário - num movimento que se arrastou por todo o século XX também, ainda que pagamento fosse ínfimo. Os chefes de família pouco a pouco se convenceram de que teriam de pagar as empregadas, costureiras, mucamas e lavadeiras. Supôs-se que esses serviços, feitos por mão de obra livre, custariam o equivalente ao de um aluguel de escravos e esse foi o preço pago e cobrado por esses serviços. Mesmo assim, o pagamento por trabalhos domésticos demorou a se estabelecer. É um assunto complexo até hoje.

Além das costureiras, as lavadeiras tomavam conta das roupas das famílias abastadas, muitas vezes acumulando funções de costura e limpeza. Era um trabalho pesado, que ocupava muitas trabalhadoras em muitos dias da semana. No começo do século XIX, Debret notava que: "Uma família rica tem sempre negras lavadeiras e uma mucama encarregada especialmente de passar as peças finas, o que a ocupa pelo menos dois dias por semana, pois uma senhora só usa roupa passada de fresco e renova mesmo sua vestimenta para sair uma segunda vez de manhã" (DEBRET, 1940, p. 274).

As famílias abastadas não economizavam as roupas que usavam, tendo também toalhas brancas, guardanapos, lençóis e diversos tipos de panos em profusão. As roupas de baixo eram particularmente difíceis de serem lavadas, pois precisavam ser limpas e alvejadas com mais constância. Em muitas casas, existiam lugares especiais para se passar, dobrar e remendar as roupas. "Sentia-se ali um cheiro especial de roupa engomada e de roupa lavada. Justificando esse cheiro, viam-se acumuladas \&\#091;...\&\#093; pilhas de camisas dobradas, montões de peças de roupa branca e, dependuradas de uma corda, pelo cós, muitas anáguas, muitas saias, penteadores bordados e vestidos de linho com guarnições de renda" (AZEVEDO, 1970, p. 13).

As maneiras de lavar a roupa variavam muito, de acordo com a região do país, e o sabão não era exatamente um produto abundante no Brasil. O que era feito aqui, caseiramente, geralmente tinha cor escura e cheiro ruim. Os sabões estrangeiros eram caros para a maioria da população. Gilberto Freyre, em Sobrados e Mocambos, notou que o sabão de lavar roupas foi um dos artigos que se industrializaram mais depressa no Brasil. "Sabão de lavar roupa-branqueada também a anil. Sabão de esfregar o corpo da gente fina e embelezá-la ainda mais. Importava-se da Europa muito sabão de luxo. \&\#091; ;..\&\#093; Um consumo enorme de sabão. A tal ponto que, no meado do século XIX, grande parte das fábricas do Império eram de sabão" (FREYRE, 2003, p. 314).

Outras maneiras de lavar as roupas eram encontradas no dia a dia, como vemos nos relatos de alguns viajantes: "Nesta região crescem, também, muitas árvores do

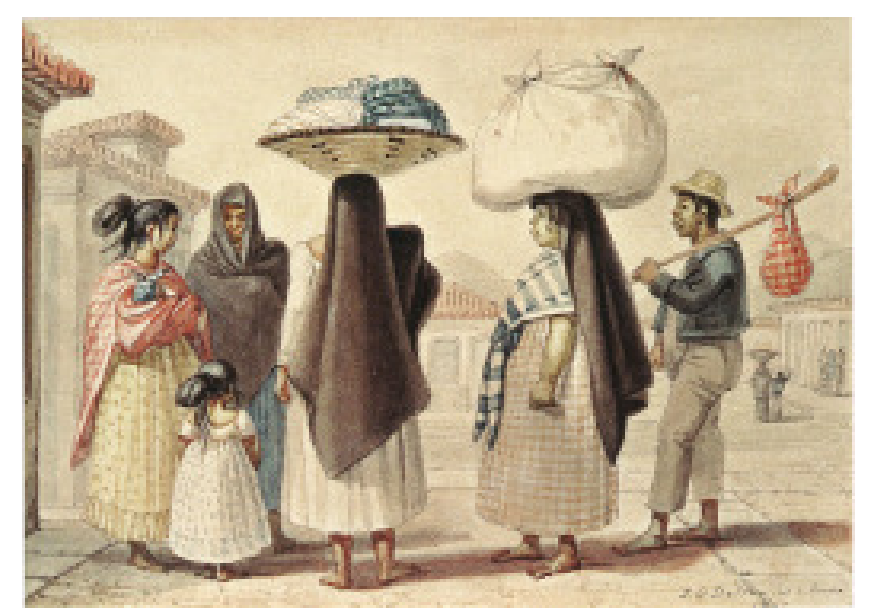

Debret: "Caboclas lavadeiras vivendo na cidade do Rio de Janeiro", cotidiano voltado para o cuidado com as roupas. (Júlio BANDEIRA; Pedro Correa do LAGO, 2008, p. 133) 
sabão \&\#091;...\&\#093; cujos frutos são levados em quantidade para a cidade. A classe mais pobre do povo emprega-os em vez do sabão, visto que o sabão fino \&\#091; ...\&\#093; está incluído entre os artigos caros da economia doméstica" (SPIX; MARTIUS, 1938, p. 175).

Usavam-se sementes e folhas para se lavarem e alvejarem as roupas, como folhas de aloés e de uma árvore chamada "timbuba". Debret nota que:

\begin{abstract}
$\& \# 091 ; \ldots \& \# 093 ;$ veem-se negras reunidas diariamente à beira do mesmo riacho límpido, ocupadas em coarar roupa ao lado das que a ensaboam de um modo infinitamente econômico, servindo-se de vegetais saponáceos como a folha de aloés e a folha da árvore chamada timbuba \&\#091;...\&\#093; bem como as de muitas outras. Assim, as lavadeiras deixam aos citadinos a despesa bastante onerosa do sabão estrangeiro, pois o que se fabrica no Brasil é de cor escura e impróprio para a roupa fina. Quanto às musselinas que não poderiam suportar a fricção de uma folha sem se esgarçarem, são lavadas estendendo-se sobre a grama, ao sol, e regando-se constantemente à medida em que secam \&\#091;...\&\#093;. Emprega-se também a bosta de cavalo e o suco de limão, este para fixar as cores de algodão estampado. (DEBRET, 1940, p. 275)
\end{abstract}

Cada tipo de roupa tinha seu jeito de ser lavada: as roupas comuns e ordinárias, com sabão da terra; as roupas finas, com sabão estrangeiro (que deveria ser economizado pelas lavadeiras); as musselinas sendo lavadas sob a grama, numa espécie de rega constante e atenta; as roupas coloridas com cocô de cavalo e suco de limão. John Mawe, ao viajar por Minas Gerais, percebeu como as plantas nativas eram usadas para diferentes tipos de lavagem de roupas e que podiam também ser usadas para outros serviços domésticos. "Estes vegetais e plantas suculentas, reduzidas a cinzas, servem para fazer sabão. Quase todos os negros conhecem o processo de fabricação respectivo, que em quase todas as famílias é empregado para uso da casa. É um sabão muito forte, que limpa muito bem tudo que é de cor branca \&\#091;...\&\#093;" (MAWE, 1978, p. 181).

Nas décadas finais do século XIX, a jornalista Júlia Lopes de Almeida, em seu livro para noivas, ensinava as mocinhas a cuidarem da roupa da família, muitas das técnicas aprendidas com mães e avós: "Para se limpar roupa preta escove-a e limpe completamente, estenda sobre a mesa a parte desejada para cima, passe uma esponja molhada com café quente coado num pedaço de musselina, quando estiver meio enxuta, passe a ferro" (ALMEIDA, 1929, p. 47). Ou para vestidos de sarja azul - "deixam-se 24 horas em águas salgada, escovam-se bem as nódoas. Enxaguam-se em água salgada, penduram-se e passam-se úmidos" (ALMEIDA, 1929, p. 47).

As lavadeiras podiam ser vistas pela cidade durante todo o dia e constituíam um grupo grande de escravos colocados para serem alugados. Maria Graham, quando chega ao Rio, escreveu:

Logo à entrada do Vale, uma pequena planície verde espraia-se para ambos os lados, através da qual corre o riacho sobre seu leito de pedras, oferecendo um lugar tentador para grupos de lavadeiras de todas as tonalidades, posto que o maior número seja de negras \&\#091;...\&\#093; Geralmente usam um lenço vermelho ou branco em volta da cabeça, uma manta dobrada e presa sobre um ombro e passando sobre o braço oposto, com uma grande saia. É a vestimenta favorita. Algumas enrolam uma manta comprida em volta delas, como indianos. Outras usam uma feia vestimenta europeia, com um babadouro bem deselegante amarrado adiante. (GRAHAM, 1956, p. 177)

Também o jornalista francês Charles Ribeyrolles notava a profusão de escravos de ganho na cidade, muitos dos quais ligados ao tratamento das roupas, tanto como mucamas, como lavadeiras: "A segunda divisão do povo negro, no Rio de Janeiro, constitui a classe numerosa dos criados de aluguel. Abri os jornais, lede os anúncios \&\#091;...\&\#093; . Aí encontrareis domésticos de mesa ou de quarto, trabalhadores, amas de crianças, lavadeiras, mucamas, cozinheiros, moços de cozinha, pajens" (RIBEYROLLES, 1941, p. 122).

A historiadora francesa Michelle Perrot recupera o tempo das lavadeiras na França, quando estas se reuniam, não apenas para lavar roupas, mas também para conversar, trocar receitas de remédios, informa-se sobre a vida na cidade e as agruras do cotidiano.

É que o lavadouro é, para elas, muito mais que um lugar funcional onde se lava a roupa: um centro de encontro onde se trocam as novidades do bairro, os bons endereços, receitas e remédios, informações de todos os tipos. Cadinhos do empirismo popular, os lavadouros são também uma sociedade aberta de assistência mútua: se uma mulher está no atoleiro, acolhemna, fazem uma coleta para ela. \&\#091;...\&\#093; uma criança abandonada certamente aí encontra sua mãe. (PERROT, 1998, p. 203)

Com os passar dos anos, no século XIX, lavar ou tingir roupas tornou-se um negócio rentável, inclusive para empresas que podiam anunciar seus serviços no Almanaque Laemmert, como fez F. A. Salingre, em 1861. Sua oficina possuía máquinas de tingir e lustrar. Lustrar seria passar a ferro? Uma espécie de lavagem a frio dos vestidos mais finos? No seu anúncio, ele diz que esse processo 
é feito sem auxílio de alfinetes e pode ser usado em seda, lã, algodão, fitas, debruns, veludos, corpinhos ou xales. Ele também tingia chapéus e tirava manchas a seco de vestidos. Sua oficina ficava na rua do Cano, 29.

Em 1871, o anúncio continuava no Almanaque Laemmert, agora com mais destaque. Salingre fazia impressões em tecidos e continuava com o negócio de tintureiro, "não tendo poupado esforços nem despesas" para igualar-se ao que de melhor havia na Europa. Continuava a tirar nódoas de fazendas, limpar a seco, tirar mofo e lavar chapéus. Era um estabelecimento com vida longa e com vasta clientela pelo Rio, e havia, nesses anos, prosperado, tendo se mudado para a rua Sete de Setembro, $29 .{ }^{3}$

Lavar roupas era um negócio no século XIX, não apenas no Brasil; uma profissão que concentrava principalmente mulheres pobres, que trabalhavam em conjunto. As lavadeiras faziam parte da paisagem das cidades, causando brigas e confusões ao redor de bicas, chafarizes e rios. Zola escreveu A Taberna (L'Assomoir), em 1876. O romance conta a história de Gervaise, uma lavadeira que ensaia um projeto de emancipação econômica, mas que, pressionada pelas circunstâncias e pelo alcoolismo, vê sua vida arruinar-se. No Rio de Janeiro, os lugares que reuniam tanta gente acabavam por se tornar locais de confusão, sendo muitas vezes alvo de batidas

72

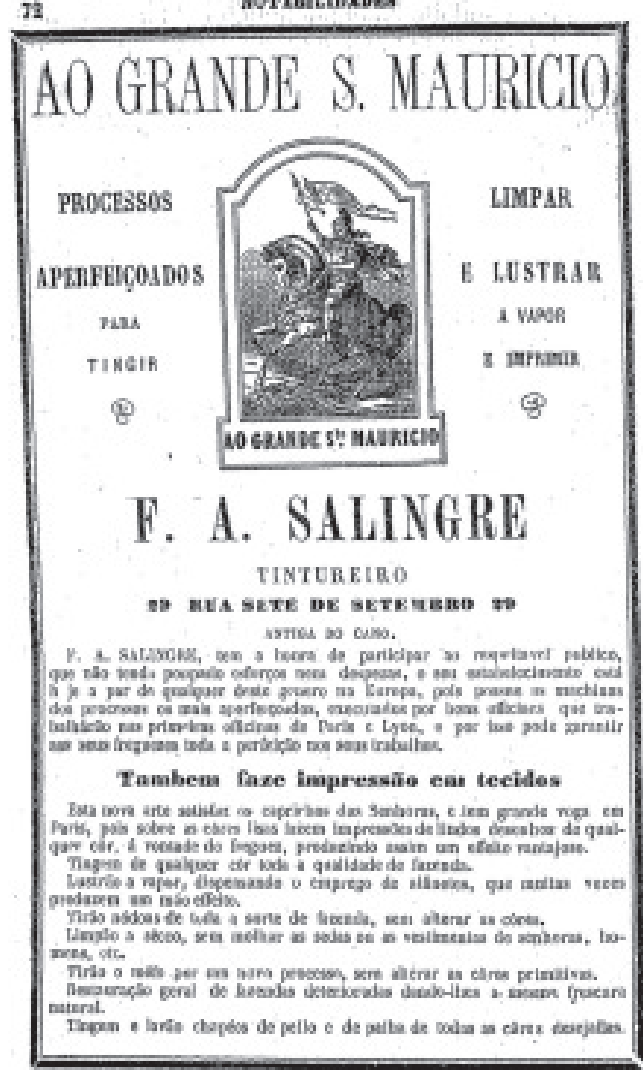

Almanaque Laemmert, $1861^{2}$ policiais. Brigas por amor, por tentativas de roubo ou mesmo por espaço ao redor das bicas e fontes de água acabavam inúmeras vezes numa profusão de palavrões.

No Rio de Janeiro de meados do século XIX, três locais principais concentravam as lavadeiras da cidade: o Chafariz das Lavadeiras, no campo de Santana, o chafariz no Largo da Carioca e o Mercado da cidade (GRAHAM, 1988, p. 51):

As casas pobres, só possuem um negro; mandam-no lavar roupa nos chafarizes da cidade, principalmente da Carioca ou do Campo de Sant'Ana, ambos cercados de vastos tanques especialmente destinados a esse fim. Por isso, aí se encontram dia e noite lavadeiras, cujo bater de roupa se houve de longe. (Daniel KIDDER, 1972, p. 132)

Lavar roupas era um serviço pesado, que envolvia não apenas esfregar com sabão ou equivalente, mas torcer e bater com força nas roupas. "Aqui vêem-se tanques de pedra onde robustas lavadeiras batem roupa \&\#091;...\&\#093;", notou Daniel Kidder, em 1838. Depois de batidas, as roupas tinham de descansar ao sol, repousadas na grama ou em arbustos. Nesse longo período de espera pelas roupas secas, as lavadeiras podiam cuidar das crianças que eventualmente as seguiam ao trabalho, ou namorar, ou mesmo apenas conversar com outras lavadeiras.

Cuidar das roupas, costurá-las, remendá-las podia também ser um pequeno negócio, no século XIX. Com o tempo, as lavadeiras e costureiras tiveram seus ofícios separados. Se por algum tempo ambas as profissões podiam andar juntas (mas isso não acontecia sempre) e as lavadeiras também faziam pequenas costuras e remendos, com a invenção da máquina de costura esse quadro vai mudar drasticamente. Ao longo do oitocentos, as costureiras vão ver seu ofício se especializar.

As máquinas de costura que se disseminaram ao longo do século XIX possibilitaram o desenvolvimento e a transformação de uma velha profissão feminina: a de costureira. Em muitos casos, as mulheres podiam costurar para fora e permanecer em casa, complementando a renda familiar enquanto faziam trabalhos de costura. O trabalho feminino mudou de maneira radical com o advento das empresas capitalistas no século XIX, e se tornou cada vez mais complexo.

As mulheres já haviam passado a fazer parte dos quadros de operários das fábricas na Europa, e a questão do trabalho feminino passou a ser extensivamente debatida, no período. No começo do século XIX, o filósofo George Hegel vai falar de uma "vocação natural" dos dois sexos, homens para o trabalho, mulheres dentro de casa, refletindo uma ideia corrente na época.

\footnotetext{
${ }^{2}$ Almanaque Laemmert 1861, seção "Notabilidades".

${ }^{3}$ Ver a seção de Notabilidades do Almanaque Laemmert 1871, p. 136.
} 
"O homem tem sua vida real e substancial no Estado, na ciência ou em qualquer outra atividade do mesmo tipo. Digamos, de modo geral, na luta e no trabalho que o opõem ao mundo exterior e a si mesmo" (HEGEL, 2009, p. 155). A mulher, pelo contrário, seria feita para a piedade e o interior. "Se se colocarem as mulheres à frente do governo, o Estado se encontra em perigo. Pois elas não agem conforme as exigências da coletividade, mas segundo os caprichos de sua inclinação e seus pensamentos" (HEGEL, 2009, p. 155). Essa ideia estava distante do cotidiano, em que mulheres eram empregadas em fábricas fora de casa, recebendo menos.

O trabalho com os tecidos e as costuras seria parte da natureza feminina, assim como os cuidados com as crianças e com a cozinha. Por outro lado, esse cuidado também era visto como uma "vocação natural" das mulheres, exposta claramente, por exemplo, na fala - recuperada pela historiadora francesa Michelle Perrot - de um delegado operário na Exposição Mundial de 1867: "A mulher, a família e os tecidos" (PERROT, 2010, p. 178). Algumas vezes essa "vocação natural" para ao cuidado com os tecidos e as costuras era utilizada para a contratação de mulheres nas fábricas e ateliês.

Ao longo das primeiras décadas do século XIX, até cerca de 1840 , quando a industrialização tomou um fôlego crescente, o debate sobre o trabalho feminino nas fábricas era intenso. Alguns pensadores reformistas, como William Gaskell, diziam que o trabalho feminino nas fábricas roubava o peito das mulheres de seus filhos, pois as impediriam de amamentar. "Outros citavam a incompatibilidade entre as mulheres e a maquinaria, contrapondo o suave e o duro, natural e artificial, futuro e presente, reprodução da espécie e produção de bens inanimados" (Joan SCOT, 1994, p. 450). Falavam da imoralidade que advinha de trabalhos pesados e clima na fábrica, dos palavrões masculinos, dos favores sexuais. ${ }^{4}$

O trabalho fora de casa estaria na alçada masculina e as mulheres não deveriam "se meter" em coisas como greves ou reivindicações (PERROT, 2010, p. 233-239). Desta maneira, o desenvolvimento da fabricação das máquinas de costura ajudou as mulheres a encontrarem uma maneira de trabalhar, ainda que dentro de casa. Era uma situação ideal para todos: as mulheres não teriam a reputação manchada ou a honra corrompida por andarem pelas ruas e fábricas, ganhariam um "extra" para ajudar na renda da casa. E, finalmente, esse trabalho não seria contabilizado como trabalho e, portanto, as mulheres sairiam da competição direta com os homens por postos de trabalhos nas fábricas. A venda de máquinas de costura domésticas foi cada vez maior ao longo do século XIX e toda a publicidade desse bem estava voltada para a compra individual.

A máquina de costura aliava o antigo trato com as agulhas, que era prerrogativa das mulheres, com uma novidade tecnológica que podia, teoricamente, ser manejada em casa, sem prejuízo dos afazeres domésticos ou do cuidado com os filhos. Foi exatamente a expansão da utilização das máquinas de costura que possibilitou um enorme aumento no número de roupas que eram vendidas prontas. Mas a máquina de costura também possibilitou a transformação do ofício de costureira ou alfaiate em algo diferente. Nasceram os ateliês de costura, onde trabalhavam várias costureiras ou alfaiates ao mesmo tempo, sob a batuta de um mestre.

A maneira como as roupas passaram a ser fabricadas também se transformou e se especializou. Se até o começo do século XIX, as roupas que eram feitas fora de casa, em costureiras, confeccionadas de uma vez só, com o passar do tempo, começou a ocorrer uma subdivisão e uma crescente especialização do trabalho da confecção de roupas. Alguns ateliês ou lojas grandes encomendavam a costureiras que trabalhavam em casa peças específicas: uma mulher podia se especializar em fazer camisas ou colarinhos, outra em pregar botões e uma terceira em fazer os punhos ou colocar rendas e ornamentos. Cada tipo de trabalho era, propositalmente, muito mal pago para que o preço da peça caísse cada vez mais. "Esse fenômeno está ligado ao desenvolvimento de uma indústria de vestuário e da roupa branca, grande forma de consumo do século XIX. Muito racionalizada, esta indústria associa fabricação em domicílio das peças, com uma intensa divisão do trabalho, e montagem em ateliês de centros urbanos" (PERROT, 2005, p. 233-234).

As máquinas de costura no Brasil começam a ser vendidas para mulheres de elite, como a condessa de Barral, e depois se popularizaram e se tornaram mais baratas (Wanderley PINHO, 1970, p. 226-227).

Para uma operária na França ou nos Estados Unidos, possuir uma máquina de costura própria seria a realização de um sonho, uma forma de possuir os meios para cuidar de sua vida, ser livre ou independente do sistema dos ateliês - ainda que ela fosse ficar o dia inteiro na máquina em casa.

Para as mulheres que imigravam para o Brasil, possuir uma máquina de costura significava um novo tipo de status social - a de uma possível possuidora de um ateliê. Em escolas, conventos

\footnotetext{
${ }^{4}$ Na França, foi revivido o "droit de cuissage" medieval, em que o dono do castelo teria o direito à primeira noite das noivas. No caso do século XIX, esse direito era reservado aos capatazes. Por causa disto, criaram-se as fábricasconvento, em que as mulheres teriam sua honra preservada.
} 
ou em casa, as meninas eram treinadas desde cedo para dominarem a máquina e se tornarem possíveis geradoras de uma renda familiar extra. Algumas famílias remediadas davam às moças que casavam uma máquina, sabendo que seria muito usada no dia a dia da fabricação das roupas familiares, mas também poderia significar uma renda extra em tempos difíceis.

Mas as máquinas de costura, assim como todo problema do trabalho feminino, causaram inúmeras controvérsias. Alguns médicos passaram a condenar o uso do aparelho, apresentando relatórios de que o movimento das pernas e pés para movimentar as máquinas causariam excitação sexual nas mulheres. A eles se uniriam alguns socialistas, preocupados em regulamentar o trabalho feminino e definir os salários masculinos. Assim, no Congresso Operário de Marselha, em 1879, em que se discutiam os rumos do movimento operário, também se levantou o problema das máquinas de costura que excitavam as mulheres: "Tal instrumento, com um movimento contínuo, excita o delírio histérico", diziam os delegados presentes (PERROT, 2005, p. 237).

Michelle Perrot percebe a associação da máquina de costura à histeria, problema feminino por excelência no século XIX. "Histérica, erótica, a máquina toca a mulher até sua intimidade mais secreta. O casal que elas formam torna-se suspeito. Aquelas pernas em perpétuo movimento não produziriam o gozo do orgasmo? Esta simbiose mulher e máquina mecaniza a mulher e sexualiza a máquina. A máquina torna-se mulher" (PERROT, 2005, p. 238).

Mas também nesse caso, a mulher é sistematicamente excluída dos processos de criação e administração das máquinas de costura, reservados aos homens, que são sempre chefes - da família e da fábrica.

No Brasil, outro tipo de emprego, além do de costureira ou lavadeira, também esteve ligado ao cotidiano feminino durante todo o século XIX: o de vendedora ou dona de estabelecimentos em que se vendiam produtos ligados à moda e ao universo feminino. A algumas mulheres era permitido ser empresária, dona loja de importações. A outras, a abertura de ateliês de costura. Geralmente imigrantes ou viúvas, essas mulheres tiveram negócios e os administrariam com relativo sucesso, empregando outras mulheres como vendedoras ou costureiras. Muitas chegaram a ter escravas trabalhando em seus ateliês como costureiras, outras foram escravas forras que aprenderam um ofício num dos ateliês da cidade do Rio de Janeiro e passaram a vender seus serviços para fora, mas algumas eram imigrantes que abriam negócios.

Catharina Dazon foi uma dessas mulheres que abriram negócios ligados à moda na rua do Ouvidor. Em 1858, madame Dazon, como era conhecida, e seu filho, possuíam uma loja que vendia "grande sortimento de sedas, cassas, chitas, bareges, camisinhas, saídas de baile, xales, rendas, chapéus de seda e palha, enfeites de cabeça, e tudo o que compõe o toalette de uma senhora". 0 estabelecimento ficava na rua do Ouvidor, no número 97. No anúncio publicado na seção de "notabilidades" do Almanaque Laemmert de 1858, aparece, no canto esquerdo, em cima, as relações comerciais de Catharina com a Europa: "Casa d'Enghien, 46, Paris. Casa em Londres e Lyon". 5

Dazon havia emigrado para o Brasil com os pais e mais cinco irmãos, no final dos anos 1810. Sua família era de Le Magne, na Suíça, região próxima a Lausanne. A família era antiga e, durante todo o século XVII, usou o sobrenome pelo qual Catharina viria a ser conhecida no Brasil, Dazon. ${ }^{6}$ Os pais, Louis e Françoise casaram-se em 1792. Tiveram seis filhos: Madeleine, François, Francillon, Anne, Catherine e Claude. ${ }^{7}$ Endividados, resolveram partir com a família num programa de imigração entre Suíça e Brasil. Os imigrantes marchariam até um porto na Holanda, de onde embarcariam. A viagem foi dura, mas, ao chegarem, tiveram de acampar em condições piores ainda. ${ }^{8}$ Assim, quando a viagem começou, a maioria dos membros da família já estava doente. Poucos dias depois do embarque, Anne morreu. Depois foi sua irmã Madeleine, sua mãe, Françoise, e seu pai, Louis. Desembarcaram no Rio de Janeiro, apenas François, Catharine e Claude. Foram para a colônia de Nova Friburgo e depois para Cantagalo. Catharine, já Catharina, começou a plantar café e teve um filho, Louis Dazon, mas nunca se casou. ${ }^{9} \mathrm{Em} 1849$, abriu sua primeira loja no Rio de Janeiro, já vendendo tecidos e roupas para senhoras e crianças.

Sua ligação com a Suíça pode ser vista no pé do anúncio do Almanaque Laemmert, na parte em que se lia que a loja vendia luvas Jouvin, um produto suíço por excelência. $O$ estabelecimento foi bem-sucedido e funcionou durante cerca de vinte anos na rua do Ouvidor. Em 1860, um cronista da Revista popular, "Carlos", ${ }^{10}$ não apenas indicou a loja de Madame Dazon para seu público leitor, como colocou a palavra de Catharina como símbolo de elegância e bom gosto: 11

\footnotetext{
${ }^{5}$ Almanaque Laemmert 1858, seção de Notabilidades, p. 33.

${ }^{6}$ Algumas vezes podemos encontrar informações sobre a família com o sobrenome de La Magne.

${ }^{7}$ Ver site sobre imigração suíça - http://www.diesbach.com/sghcf/m/magne.html, consulta em 15/08/2012.

${ }^{8}$ Ver site sobre imigração suíça http://www.diesbach.com/sghcf/m/magne.html, consulta em 15/08/2012.

${ }^{9}$ Ver site sobre imigração suiça http://www.diesbach.com/sghcf/m/magne.html, consulta em 15/08/2012.

10 O nome "Carlos" era um pseudônimo.

11 Para uma explicação mais detalhada sobre as crônicas da Revista Popular, ver artigo de Marcella dos Santos Abreu, (2008) "Paquetes, modas e salões: o desejo mimético nas crônicas da Revista popular (1859-1862)".
} 
Agora que nos vamos ocupar da explicação dos tesouros que mais agradaram ao artista emissário, permiti que eu ceda a palavra a Mme. Catharina Dazon, para vos fazer a Descrição da gravura de modas. (...) É ocioso lembrar-vos, que Mme. Catharina Dazon \& Filho recebem por todos os paquetes a melhor escolha de artigos modernos e se incumbem de dar vida aos figurinos sujeitos ao seu hábil sistema de interpretar as criações artísticas. (CARLOS, 1860, p. 255256)

Como madame Dazon, outras mulheres também foram donas de lojas e armazéns no Rio de Janeiro imperial. Estabelecimentos como o de madame C. Creten \& Cie, À Ville de Bruxelas, localizado à rua do Ouvidor, 70 , vendia camisas e ceroulas sob medida, assim como roupas de banho e roupões felpudos e também meias, lenços, gravatas e colarinhos, panos de algodão e linhos, "oxfords e cambraias de cor"; 12 ou a loja de madame A. C. Favre, Ao Bastidor de Bordar, que comercializava lãs, sedas, frocos, miçangas, algodões, agulhas, crochês, talagarças, vidrilhos, desenhos para bordar e "tudo que é necessário para costuras". ${ }^{13}$

As rendas, chapéus, xales, mantôs, vidrilhos de enfeitar, contas, missangas, punhos, golas eram itens, muitas vezes importados, que transformavam as roupas das mulheres e homens e podiam significar a diferença social entre "estar na moda" ou não. O escritor Aluísio Azevedo ao descrever um personagem dizia: "Fraque à inglesa! Colarinho da moda! Plastron! Meias de cor! Polainas! Sapatos de verniz! Flor à gola!" (AZEVEDO, 1960, p. 49). E já dizia tudo. As casas que abasteciam o mercado carioca sabiam desse poder social e jogavam com estrangeirismos $e$ objetos importados. Se a costureira ou o alfaiate fosse estrangeiro, melhor para os negócios. Muitas vezes, as mulheres imigrantes se aproveitavam desse fato para abrirem suas casas de comércio. Algumas comerciantes, inclusive, passaram a vender não apenas os vidrilhos, miçangas, luvas e sapatos, que caracterizavam o mercado de negócios para mulheres. Essas mulheres entraram no negócio de comercializar máquinas, as mais modernas do século XIX - desde beneficiadoras de café até máquinas de costura.

Madame Besse foi uma dessas negociantes e estabeleceu-se como fornecedora oficial da família real. Toda a transformação dos cuidados com as roupas no século XIX se traduziu na especificação e na diversificação de profissões ou ofícios femininos ligados às próprias roupas.

Mucamas, lavadeiras, costureiras, vendedoras se tornaram profissões femininas por excelência, por vocação natural das mulheres no trato com roupas - mesmo que isso implicasse na utilização de uma máquina moderna, a de costuras, com novos métodos de produção que incorporaram antigos hábitos e visões de mundo, como a que via a mulheres dentro do espaço doméstico.

Ao mesmo tempo, as mulheres puderam sair às ruas para consumir, em busca de mercadorias que incrementaram esse comércio e essas transformações - e foram atendidas por uma nova profissão feminina, a vendedora ou lojista. Consumo e produção andaram juntas nas mudanças que tiveram lugar no século XIX, que influenciariam enormemente o trabalho feminino.

\section{Referências}

ABREU, Marcella dos Santos. "Paquetes, modas e salões: o desejo mimético nas crônicas da Revista popular (1859-1862)". In: Anais do Seta, vol. 2, 2008, p. 7-12.

ALENCAR, José de. Lucíola. São Paulo: Edições Melhoramentos, 2012.

ALMANAQUE LAEMMERT. "Notabilidades”. Rio de Janeiro, 1858.

ALMANAQUE LAEMMERT. "Notabilidades". Rio de Janeiro, 1861.

ALMANAQUE LAEMMERT. "Notabilidades". Rio de Janeiro, 1868

ALMANAQUE LAEMMERT. “Notabilidades”. Rio de Janeiro, 1871.

ALMEIDA, Julia Lopes de. O livro das noivas. Rio de Janeiro: Castorino Mendes, 1929.

ASSIS, Joaquim Maria Machado de. Memórias póstumas de Brás Cubas. São Paulo: Editora Ática, 1999.

AZEVEDO, Aluísio. Girândola de amores. São Paulo: Martins Editora, 1960.

AZEVEDO, Aluísio. O homem. São Paulo: Martins Editora, 1970.

AZEVEDO, Aluísio. Casa de pensão. São Paulo: Martins Editora, 1960.

12 Anúncio publicado no Almanaque Laemmert 1868, seção de Notabilidade, p. 54.

${ }^{13} \mathrm{O}$ anúncio de madame Favre foi publicado no Almanaque Laemmert paral 858, seção de Notabilidades, p. 38. 
BANDEIRA, Julio; LAGO, Pedro Correa do. Debret e o Brasil. Obra completa. Rio de Janeiro: Capivara, 2008.

CARLOS. Revista Popular, Rio de Janeiro, 1860, p. 255-256).

CARVALHO, Vania Carneiro. "Gênero e artefato". O sistema doméstico na perspectiva da cultura material. (São Paulo 1870-1920). São Paulo: Edusp, 2008.

DEBRET, Jean-Baptiste. Viagem pitoresca e histórica ao Brasil. Tomo I, vol. I e II, São Paulo: Martins Editora, 1940.

DIAS, Maria Odila Leite da Silva. Quotidiano e poder em São Paulo no séc. XIX. São Paulo: Brasiliense, 1984.

FREYRE, Gilberto. O escravo nos anúncios de jornais brasileiros do século XIX. São Paulo: Companhia Editora Nacional, col. Brasiliana, 1979.

FREYRE, Gilberto. Sobrados e mucambos. São Paulo: Global, 2003.

GINZBURG, Natalia. Léxico familiar. São Paulo: Cosac \& Naify, 2009.

GRAHAM, Maria. Diário de uma viagem ao Brasil e de uma estada nesse país durante parte dos anos de 1821, 1822, 1823. São Paulo: Companhia Editora Nacional, 1956.

GRAHAM, Richard. Alimentar a cidade: das vendedoras de rua à reforma liberal. São Paulo: Companhia das Letras, 2013.

GRAHAM, Richard. Grã-Bretanha e o início da modernização no Brasil (1850-1914). São Paulo: Brasiliense, 1973.

GRAHAM, Sandra Lauderdale. Proteção e obediência. Criadas e patrões no Rio de Janeiro. 18601910. São Paulo: Companhia das Letras, 1988.

HEGEL, Georg. Princípios da filosofia do Direito. Tradução portuguesa. São Paulo: Martins Fontes, 2009.

KIDDER, Daniel Parish. Reminiscências de viagens e permanência no Brasil, províncias do Norte. São Paulo: EDUSP/Itatiaia Editora, 1972.

MALUF, Marina. Ruídos da memória. São Paulo: Siciliano, 1994.

MAWE, John. Viagens ao interior do Brasil. São Paulo, Belo Horizonte: EDUSP/ Itatiaia Editora, 1978.

PERROT, Michelle. Os excluídos da história: operários, mulheres e prisioneiros. São Paulo: Paz e Terra, 2010.

PERROT, Michelle. Mulheres públicas. São Paulo: Editora da Unesp, 1998.

PERROT, Michelle. As mulheres ou os silêncios da história. Bauru: Edusc, 2005.

PINHO, Wanderley. Salões e damas do segundo império. São Paulo: Martins Editora, 1970.

RIBEYROLLES, Charles. Brasil pitoresco. Vol. I, São Paulo: Martins Editora, 1941.

SCOTT, Joan. "A mulher trabalhadora". In: História das mulheres, o século XIX. Lisboa: Afrontamento, 1994, vol. IV.

SOUZA, Gilda de Mello. O espírito das roupas: a moda no século XIX. São Paulo: Companhia das Letras, 1987.

SPIX, Johann Baptiste von; MARTIUS, Carl Friedrich Philippe Von. Viagem pelo Brasil. Vol. I, Rio de Janeiro: Imprensa Nacional, 1938.

Joana de Moraes Monteleone (iD) 0000-0002-0035-4293

Pós-doutorado na Universidade Federal de São Paulo (UNIFESP-SP)

Fez doutorado pelo Programa de Pós-Graduação em História Econômica da Universidade de São Paulo (USP- SP/2013) com o título de "O circuito das roupas: a corte, o consumo e a moda. Rio de Janeiro 1840-1889", sob orientação de Professora Titutlar Vera Lúcia Amaral Ferlini. Possui mestrado, 
também orientado pela professora Vera Ferlini, em História Econômica pela mesma instituição (USP/ 2008), com o título de "Sabores urbanos: alimentação, sociabilidade e consumo. São Paulo, 18281910". É co-organizadora do livro "A história na moda, a moda na história" (São Paulo: Alameda Casa Editorial, 2018), juntamente com Paulo de Debom e Camila Borges; e é autora dos livros "Sabores urbanos: alimentação, sociabilidade e consumo. São Paulo, 1828-1910" (São Paulo: Alameda Casa Editorial, 2015) e "Toda comida tem uma história" (Rio de Janeiro: Oficina Raquel, 2017). Atualmente trabalha com as seguintes linhas de pesquisa: História do Consumo, História do Império no Brasil, História da Alimentação e da Moda.

Universidade Federal de São Paulo, Departamento de História

Estr. do Caminho Velho, 333 - Jardim Nova Cidade

07252-312 - Guarulhos - SP - Brasil

(11) 5576-4848

Joana@alamedaeditorial.com.br

\section{COMO CITAR ESSE ARTIGO DE ACORDO COM AS NORMAS DA REVISTA}

MONTELEONE, Joana de Moraes. "Costureiras, mucamas, lavadeiras e vendedoras: O trabalho feminino no século XIX e o cuidado com as roupas (Rio de Janeiro, 1850-1920) ". Revista Estudos Feministas, Florianópolis, v. 27, n. 1, e48913, 2019.

\section{CONTRIBUIÇÃO DE AUTORIA}

Não se aplica

\section{FINANCIAMENTO}

Não se aplica

\section{CONSENTIMENTO DE USO DE IMAGEM}

Não se aplica

APROVAÇÃO DE COMITÊ DE ÉTICA EM PESQUISA

Não se aplica

\section{CONFLITO DE INTERESSES}

Não se aplica

\section{LICENÇA DE USO}

Este artigo está licenciado sob a Licença Creative Commons CC-BY. Com essa licença você pode compartilhar, adaptar, criar para qualquer fim, desde que atribua a autoria da obra.

\section{HISTÓRICO}

Recebido em 08/02/2017.

Reapresentado em 04/05/2018.

Aprovado em 05/07/2018.

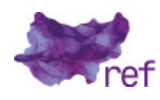

